\title{
Developing a scale to measure employee service quality in Indian SMEs
}

\author{
Surjit Kumar Gandhi*, Anish Sachdeva and Ajay Gupta
}

Department of Industrial and Production Engineering, Dr. B. R. Ambedkar National Institute of Technology, Jalandhar-144 011, Punjab, India

\begin{tabular}{l}
\hline C H R O N I C L E \\
\hline Article history: \\
Received: November 26, 2017 \\
Received in revised format: Janu- \\
ary 31, 2018 \\
Accepted: March 30, 2018 \\
Available online: \\
March 30, 2018 \\
\hline Keywords: \\
Employee Service quality (ESQ) \\
Measurement scale \\
Small-medium manufacturing \\
units \\
EFA \\
CFA \\
Reliability \\
Validity
\end{tabular}

\section{A B S T R A C T}

\begin{abstract}
The objective of the present study is to bring out a multidimensional metric to measure service quality delivered by employees serving in Indian small \& medium manufacturing enterprises. 144 executives working at top/middle level in different small-medium manufacturing units of north India responded to a questionnaire survey. The respondents were asked to assess service quality being delivered by the shop-floor workers serving their respective units on the $1-5$ perception scale. Application of exploratory factor analysis resulted in an interpretable latent structure comprising of 5 determinants and 22 indicator items. Confirmatory factor analysis condensed this scale to bring out the final scale 4 determinants viz., Dependability, Agility, Professionalism and Understanding with 13 indicator statements. This scale thus emerged is tested for validity and reliability using established tools. The study provides a framework to SME managers to assess services of their workforce. It also contributes to researchers to build up more such metrics for similar situations in other sectors so that more concrete generalizations can be made.
\end{abstract}

(C) 2018 by the authors; licensee Growing Science, Canada

\section{Introduction}

A manufacturing unit is a chain of smaller functional units, each of which is an independent producer and converts inputs into outputs that are used by other internal customers across functional units and hierarchical levels (Dodson, 1991). Thus, an employee's role should include improving relationships with his/her internal customers and then developing a process to raise the quality of their internal products and services. Thus, internal customer service is a two-way exchange process between co-workers, with each one of them made responsible for catering to the requirements of his/her internal customers. (Bowersox et al., 1999; Stank et al., 2001). Research demonstrates that services delivered by employees have strong linkages with business performance, sustainability, growth and profitability (Sureshchander et al., 2002). Appreciating and tapping employee performance as the most valuable intangible asset, may generate most of corporate growth and shareholder value (Lev, 2004). Globally manufacturing organizations are transforming themselves for competition that is based on their ability to exploit abilities of their pool of workforce than their ability to invest in and manage physical assets (Smith et al., 2014; Bustinza et al., 2015).

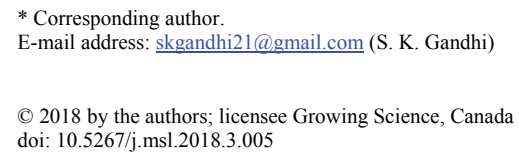


From the supply chain perspective, service quality (SQ) needs to be ascertained across the value chain and must include employees of the manufacturing unit (Bowen \& Schneider, 1988). Employee service quality (ESQ) refers to the manner in which employees of the manufacturing unit serve other employees and what attitudes they hold towards them. Thus, the co-workers up and down the value-chain that one serves are considered internal customers, and internal customer service is an integral part of most service quality efforts. The practitioners in such units must appreciate value of "viewing the next operation as customer", as a part of their manufacturing strategy to improve working within the unit (Stanley \& Wisner, 2002; Sotoudeh-Anvari et al., 2018).

Small and medium enterprises (SMEs) occupy a place of strategic importance in the economic growth of India. With globalization, domestic economic liberalization and sector-specific reforms, these enterprises are finding themselves in an intensely competitive environment. Despite being unanimous about the importance of SQ, there is hardly any metric available to managers w.r.t. human factor in these units (Seth et al., 2006; Prakash, 2011). To remain competitive, the need for such units is to gradually shift their total offering as a manufacturer from mostly tangibles to include services, and finally, develop into a relationship-focused offering (Nix, 2001). Researchers also agree that service quality must be ascertained across the whole value network of an enterprise with a wider domain including employees (Gupta \& Singh, 2015, 2017; Seth et al., 2008; Prakash, 2014). It is thus realized that industrial firms need a reliable tool, to measure employee service quality and identify various attributes impacting the elusive construct of ESQ for its better measurement and control. To achieve this goal, a comprehensive review of extant literature, coupled with expert interviews was conducted, which resulted in the development of a questionnaire. Various tests for validation were performed to examine the underlying dimensions. In order to gain the insights of relative importance of these dimensions contributing to overall service quality, regression analysis was also conducted (Gandhi et al., 2018).

\section{Literature review}

Services typically comprise a 'how' and a 'what' element. 'What' reflects the output of the service, i.e., what is delivered to employees? The 'how' of service deals with the processes of service delivery, i.e., the way it is delivered? Production, delivery and consumption of services are usually integrated, and service delivery often depends on and is influenced by the attitude of recipient towards the service (Grönroos, 1990). The recipient and provider have a close interface and sometimes personal relationship. Because of the involvement of the human element, there is likely to be variability in service provision. Because services are intangible, it is difficult to apply standards in a rigorous and consistent manner. It is difficult to delineate process boundaries, identify check points and exercise control. Moreover, with services, it is difficult to control and regulate environmental conditions. Therefore, for business success, the imperative is to conceptualize, design and monitor SQ (Cronin and Taylor, 1992). Often, managements of industrial units have measure employee performance in terms of delivering productivity than serving customers with unique needs (Bowen \& Schneider, 1988). Consequently, employees do not perceive their function as service providers to internal customers, but rather as meeting external demand from consumers. Service quality to internal customers is equally important to create synergy thereby serving external customers in a better way (Hallowell et al., 1996). By fostering such win-win strategy, industrial units can increase their profits and can successfully compete in the external market (George, 1990; Magidson \& Polcha, 1992). Implicitly speaking, manufacturing units can only effectively manage supply chains when internal operations are running smoothly. Some of the typical benefits of treating the manufacturing unit as a channel partner in supply chain can be envisaged as ensuring proper flow of man, materials and services; helping top management to focus on strategic issues; and help in enhancing service to both upstream and downstream partners. 


\subsection{Reviewing Recent Service Quality Models}

In this section, we make an attempt to evaluate 25 industry specific SQ models evolved in the new millennium under continuously changing business environment. Each model is analyzed through the major observations and the limitations thereof. These models are summarized below in Table 1:

\section{Table 1}

Summary Evaluation of Service Quality Models in the new millennium

\begin{tabular}{|c|c|c|}
\hline Model No. & $\begin{array}{l}\text { Key Findings } \\
\end{array}$ & $\begin{array}{c}\text { Limitations } \\
\end{array}$ \\
\hline $\begin{array}{l}\text { Antecedents and media- } \\
\text { tor model }\end{array}$ & $\begin{array}{l}\text { - Besides making an evaluation of determinants of service quality, con- } \\
\text { sumers do make an overall evaluation of the service quality, which may } \\
\text { not be simply the sum of individual factors. } \\
\text { The model attempts at providing a thorough qualitative understanding } \\
\text { of service perceptions and their formations. } \\
\text { Customer satisfaction was recognized as a construct different from the } \\
\text { service quality. }\end{array}$ & $\begin{array}{l}\text { - Antecedents of customer satisfaction are not } \\
\text { investigated. } \\
\text { - The model indicates behavioral intentions and } \\
\text { not the actual behavior. } \\
\text { A generalized standard scale is not provided, } \\
\text { thus the model cannot be emulated in different } \\
\text { service situations. }\end{array}$ \\
\hline $\begin{array}{l}\text { SQ } 02 \\
\text { (Frost and Kumar, } \\
\text { 2000) }\end{array}$ & $\begin{array}{l}\text { - The model postulated the role played by perceptions and expectations } \\
\text { of intrinsic customers. } \\
\text { - The intrinsic service provider \& intrinsic service customer play a major } \\
\text { role in recognizing the level of service quality perceived. }\end{array}$ & $\begin{array}{l}\text { - It needs to be generalized for all kinds of in- } \\
\text { trinsic environments. } \\
\text { The effect of variations in extrinsic environ- } \\
\text { ment is not taken into account. }\end{array}$ \\
\hline $\begin{array}{l}\text { SQ } 03 \\
\text { (Soteriou and Stav- } \\
\text { rinides, 2000) } \\
\text { ISQ Data envelope analy- } \\
\text { sis model }\end{array}$ & $\begin{array}{l}\text { - This model indicates the input resources like personnel, space, time, etc. } \\
\text { The above resources should be more efficiently utilized to produce } \\
\text { higher service quality level perceived by the internal employees of the } \\
\text { branch. }\end{array}$ & $\begin{array}{l}\text { - The model does not bring out attributes of ser- } \\
\text { vice quality, and only guides how available } \\
\text { resources can be utilized for improved ISQ } \\
\text { experiences. } \\
\text { Traditional measures are not incorporated in } \\
\text { the model. }\end{array}$ \\
\hline $\begin{array}{l}\text { SQ } 04 \\
\text { (Brady and Cronin, } \\
\text { 2001) } \\
\text { The Hierarchical ap- } \\
\text { proach }\end{array}$ & $\begin{array}{l}\text { - The model attempts to combine the two classical schools of thought - } \\
\text { the European and the American and conclude that neither fully captures } \\
\text { the construct. } \\
\text { Service quality is a multidimensional hierarchical construct having three } \\
\text { prime attributes- output, quality of interaction and environment. }\end{array}$ & $\begin{array}{l}\text { - No empirical evidence has been provided for } \\
\text { this hierarchical structure. } \\
\text { It does not propose an instrument to evaluate } \\
\text { service quality. }\end{array}$ \\
\hline $\begin{array}{l}\text { SQ } 05 \\
\text { (Zhu } \text { et al., 2002) }\end{array}$ & $\begin{array}{l}\text { - Service quality has a direct influence on three SERVQUAL determi- } \\
\text { nants namely reliability, responsiveness \& assurance. } \\
\text { IT tools can aid service providers to enhance higher levels of client/user } \\
\text { satisfaction. }\end{array}$ & $\begin{array}{l}\text { - Less number of determinants were selected to } \\
\text { measure the feeling of satisfaction and com- } \\
\text { fort. } \\
\text { It does not propose an instrument to evaluate } \\
\text { IT-based service quality. }\end{array}$ \\
\hline $\begin{array}{l}\text { SQ } 06 \\
\text { (Behara } \text { et al., 2002) } \\
\text { Reverse SERV-QUAL } \\
\text { Model }\end{array}$ & $\begin{array}{l}\text { - Different definitions of service quality measurement are modeled using } \\
\text { the neural network approach. } \\
\text { - It gives a Reverse SERVQUAL model for possible neural networks. }\end{array}$ & $\begin{array}{l}\text { - Due to noisy data, the research had limited } \\
\text { success with sensitivity analysis. }\end{array}$ \\
\hline $\begin{array}{l}\text { SQ } 07 \\
\text { (Santos, 2003) } \\
\text { E-service quality model }\end{array}$ & $\begin{array}{l}\text { - It offers a better understanding of e-service quality for achieving cus- } \\
\text { tomer satisfaction leading to customer retention followed by profitabil- } \\
\text { ity. } \\
\text { - This model can be useful to organizations using e-commerce. }\end{array}$ & $\begin{array}{l}\text { It involves exploratory study. The model does } \\
\text { not provide specific measurement scales. } \\
\text { No statistical analysis is carried out. }\end{array}$ \\
\hline $\begin{array}{l}\text { SQ } 08 \\
\text { (Kang and James, 2004) }\end{array}$ & $\begin{array}{l}\text { - Technical, and functional service features in conjunction with image of } \\
\text { service provider organization may fully capture the construct of overall } \\
\text { service quality. } \\
\text { Both the Grönroos's model (1984) and PZB SERVQUAL (1988) mod- } \\
\text { els are tested and empirically validated. } \\
\text { - The model assumes that customers are enough competent to assess tech- } \\
\text { nical quality. }\end{array}$ & $\begin{array}{l}\text { - Places too much emphasis on technical qual- } \\
\text { ity } \\
\text { The model overlooks the dominance of func- } \\
\text { tional quality as compared to technical quality } \\
\text { in certain situations. }\end{array}$ \\
\hline $\begin{array}{l}\text { SQ } 09 \\
\text { (Parasuraman et al., } \\
\text { 2005) } \\
\text { E-S-QUAL Model }\end{array}$ & $\begin{array}{l}\text { - The model develops a multiple-item scale (E-S-QUAL) to measure the } \\
\text { service quality offered by two chosen websites amazon.com and } \\
\text { Walmart.com enjoying high frequency of visits. } \\
\text { The basic scale comprises four attributes and } 22 \text { item, whereas E-RecS- } \\
\text { QUAL scale (involving recovery) has three attributes and 11-item scale. }\end{array}$ & $\begin{array}{l}\text { - Robust and sturdy websites were chosen for } \\
\text { survey which had low incidents of problem } \\
\text { encounters. } \\
\text { Valid for goods only and pure-services are out } \\
\text { of scheme of this model. }\end{array}$ \\
\hline $\begin{array}{l}\text { SQ } 10 \\
\text { (Park et al., 2005) }\end{array}$ & $\begin{array}{l}\text { - The model confirms that service quality must be enhanced to make pas- } \\
\text { sengers' experience a delight. } \\
\text { - Two most significant determinants were churned out namely, "in-flight } \\
\text { service" "convenience and accessibility". } \\
\text { - The above dimensions have a significant effect on airline image, which } \\
\text { in turn has a significant effect on passengers' behavioral intention. }\end{array}$ & $\begin{array}{l}\text { - The determinants of reliability and customer } \\
\text { service were not tested for validity. } \\
\text { Only economy class- domestic passengers } \\
\text { were included in survey. }\end{array}$ \\
\hline $\begin{array}{l}\text { SQ } 11 \\
\text { (Olorunniwo and Hsu, } \\
\text { 2006) } \\
\text { Mass service quality } \\
\text { model }\end{array}$ & $\begin{array}{l}\text { - The service managers must develop operational strategies that focus on } \\
\text { various aspects of service quality. } \\
\text { Customer satisfaction fully mediates the impact of service quality on } \\
\text { behavioral intention. }\end{array}$ & $\begin{array}{l}\text { - The study is conducted for mass services } \\
\text { only. } \\
\text { The work uses only one organization for data } \\
\text { collection. }\end{array}$ \\
\hline
\end{tabular}




\section{Table 1}

\section{Summary Evaluation of Service Quality Models in the new millennium (Continued)}

\begin{tabular}{|c|c|c|}
\hline Model No. & Key Findings & Limitations \\
\hline $\begin{array}{l}\text { SQ } 12 \\
\text { (Olorunniwo et al., } \\
\text { 2006) } \\
\text { Service Factory Model }\end{array}$ & $\begin{array}{l}\text { - Although the direct effect of service quality on behavioral intention is } \\
\text { significant, the indirect effect is a stronger driver for behavioral inten- } \\
\text { tions mediated through satisfaction. }\end{array}$ & $\begin{array}{l}\text { - The study uses only one industry (hotel indus- } \\
\text { try). } \\
\text { It partly attempts to validate classification } \\
\text { scheme of Schmenner }(1986,2004) \text {. }\end{array}$ \\
\hline $\begin{array}{l}\text { Kang's hierarchical struc- } \\
\text { ture of service quality }\end{array}$ & $\begin{array}{l}\text { - The model endorses PZB (1988) American school of thought and vali- } \\
\text { dates dimensions of functional (subjective) quality. } \\
\text { This model gives empirical evidence for its hypotheses regarding tech- } \\
\text { nical quality and functional quality components. }\end{array}$ & $\begin{array}{l}\text { - The proposed hierarchical structure is not em- } \\
\text { pirically validated. } \\
\text { It does not propose an instrument to evaluate } \\
\text { service quality. }\end{array}$ \\
\hline $\begin{array}{l}\text { Service Quality in Supply } \\
\text { Chains }\end{array}$ & $\begin{array}{l}\text { This research offers managers with a practical framework for service } \\
\text { quality improvements that measures service quality. } \\
\text { The work suggests the ways to achieve customer satisfactions and fo- } \\
\text { cuses on sustained growth differentiation strategy for supply chain. }\end{array}$ & $\begin{array}{l}\text { Environmental factors are not considered in } \\
\text { study. } \\
\text { The items linking to organization's strategy } \\
\text { are not included in this framework. }\end{array}$ \\
\hline $\begin{array}{l}\text { SQ } 15 \\
\text { (Car, 2007) }\end{array}$ & $\begin{array}{l}\text { - The model accepts PZB (1988) service quality model using percep- } \\
\text { tions-only scale though it uses equity (fairness) in addition as a signif- } \\
\text { icant determinant. } \\
\text { - The service seekers (customers) are essentially concerned if they get } \\
\text { what they are getting the desired value, and in contrast to others. }\end{array}$ & $\begin{array}{l}\text { - The study was limited to intrinsic service } \\
\text { quality only. } \\
\text { Generalizations are not possible since items } \\
\text { on extrinsic service quality were not included } \\
\text { in survey. }\end{array}$ \\
\hline $\begin{array}{l}\text { A Hierarchical Model of } \\
\text { Health Service Quality }\end{array}$ & $\begin{array}{l}\text { - This research designed and fully validated a multidimensional hierar- } \\
\text { chical service quality scale suitable for health services. } \\
\text { Satisfaction and favorable behavioral intentions were included as out- } \\
\text { come variables in the study. } \\
\text { The conclusions support the hypothesis that that service quality medi- } \\
\text { ates the relationship between SQ dimensions and intention. }\end{array}$ & $\begin{array}{l}\text { - The cross-sectional design of the study may } \\
\text { pose a problem and limits generalization. } \\
\text { The study doesn't provide a dynamic model } \\
\text { of service evaluation. }\end{array}$ \\
\hline $\begin{array}{l}\text { SQ } 17 \\
\text { Wattanakamolchai } \\
\text { (2008) } \\
\text { Socially Responsible } \\
\text { Customer } \\
\text { SQ Model }\end{array}$ & $\begin{array}{l}\text { - The study explores "social responsibility" determinant for measuring } \\
\text { the service quality using second order CFA. } \\
\text { - The study differentiated highly socially responsible customers from } \\
\text { those less socially responsible ones. }\end{array}$ & $\begin{array}{l}\text { - It was not convenient to identify the respond- } \\
\text { ents. } \\
\text { Aspects like, "service personnel appearance" } \\
\text { and "store accessibility" are difficult to recall. }\end{array}$ \\
\hline $\begin{array}{l}\text { SQ } 18 \\
\text { Ghosh and Srivastava } \\
(2009) \\
\text { Commitment and Trust } \\
\text { based Service Quality } \\
\text { model }\end{array}$ & $\begin{array}{l}\text { - The major contribution of the study was the identification and measure- } \\
\text { ment of customer's perception of service quality dimensions and their } \\
\text { relative importance for increasing loyalty, commitment, and trust. } \\
\text { They organization pay attention to these variables to strengthen compet- } \\
\text { itiveness in an extremely competitive market. }\end{array}$ & $\begin{array}{l}\text { - Other variables like pricing, technology, lo- } \\
\text { gistics etc. should have been considered in } \\
\text { study. } \\
\text { - A relatively sample size was used. } \\
\text { - Findings are not generalizable. }\end{array}$ \\
\hline $\begin{array}{l}\text { SQ } 19 \\
\text { Kuo and Tsai } \\
\text { (2009) } \\
\text { Model for } \\
\text { Real Estate Brokerage In- } \\
\text { dustry }\end{array}$ & $\begin{array}{l}\text { - The findings show that the soft (non-core service) service attributes have } \\
\text { a significant influence on hard (core service) service attributes. } \\
\text { The results have positive relationship between service attributes and re- } \\
\text { lationship quality. Perceived performance Excellence (PPE) mediates } \\
\text { between soft service quality and relationship quality. } \\
\text { Relationship quality has a significant influence on behavioral intention. } \\
\text { That means customers' satisfaction and trust established will improve } \\
\text { positive word- of-mouth and repeated patronage. }\end{array}$ & $\begin{array}{l}\text { - The study is performed in a single small sec- } \\
\text { tor. } \\
\text { This study adopted the classified service at- } \\
\text { tributes by Auh }(2005) \text { and proposed a con- } \\
\text { ceptual model to explore the direct and indi- } \\
\text { rect effect between the customer perceived } \\
\text { service attributes and behavioral intention. }\end{array}$ \\
\hline $\begin{array}{l}\text { SQ } 20 \\
\text { Kelkar (2010) } \\
\text { SERVDIV model }\end{array}$ & $\begin{array}{l}\text { - Kelkar (2010) developed a new scale labeled SERVDIV by taking cues } \\
\text { from ancient Indian scripture Atharva Veda guideline, "Guest is divine } \\
\text { (Customer is the king)" } \\
\text { The three attributes suggested to "serve (worship) the divine guest (cus- } \\
\text { tomer) are through the paths of knowledge, action and submission". }\end{array}$ & $\begin{array}{l}\text { - It model states a hypothetical proposition. } \\
\text { - No statistical analysis is carried out. }\end{array}$ \\
\hline $\begin{array}{l}\text { Service quality model for } \\
\text { Life Insurance Business }\end{array}$ & $\begin{array}{l}\text { - The model is developed using ANN approach and has been adequately } \\
\text { validated for all stakeholders in the service network. } \\
\text { The study reveals that best-fit model does not contain the construct of } \\
\text { patronage intention, which means. This conclusion challenges the tradi- } \\
\text { tional viewpoints prevailing in this sector. }\end{array}$ & $\begin{array}{l}\text { - This convenience sampling and anonymous } \\
\text { survey- based research pose limitations to re- } \\
\text { sults of this model. } \\
\text { - Single service industry has been surveyed for } \\
\text { conducting the study. }\end{array}$ \\
\hline $\begin{array}{l}\text { SQ } 22 \\
\text { Prakash (2011) } \\
\text { Service Quality in Auto- } \\
\text { motive Industry }\end{array}$ & $\begin{array}{l}\text { - The models endorses the conclusions drawn by Seth et al. (2006) in the } \\
\text { supply chains of three select large scale automobile organizations. } \\
\text { It models both intrinsic and extrinsic service quality at different dyads } \\
\text { of supply chain. } \\
\text { The study proposes complete structural model with loyalty, competitive } \\
\text { advantage and unit's performance used as outcome variables. }\end{array}$ & $\begin{array}{l}\text { - Only three automotive units under study and } \\
\text { snowball sampling method diminish general- } \\
\text { izability of the findings. } \\
\text { The research doen't consider technical quality } \\
\text { attributes into consideration. }\end{array}$ \\
\hline $\begin{array}{l}\text { SQ } 23 \\
\text { Das and Pandit (2014) }\end{array}$ & $\begin{array}{l}\text { In this research, a method has been developed to determine the transit } \\
\text { service delivery levels using the concept of users' and potential users' } \\
\text { minimum acceptable service and desired service level. } \\
\text { It is suggested, based on the availability of resources, service provid- } \\
\text { ers need to prioritize certain service areas for improvement. }\end{array}$ & $\begin{array}{l}\text { - The scale developed in this research is based } \\
\text { on users' perceived service levels which may } \\
\text { differ from the actual service levels. } \\
\text { - Ordered categorical scales limited the use of } \\
\text { 'median' only to aggregate the results. }\end{array}$ \\
\hline $\begin{array}{l}\text { SQ } 24 \\
\text { Parmata (2016) } \\
\text { Pharmaceutical Distribu- } \\
\text { tion Service Quality } \\
\text { Model }\end{array}$ & $\begin{array}{l}\text { It In this a valid distributor perceived SQ (DSQ) metric is developed } \\
\text { using EFA and CFA thereby identifying four determinants namely - re- } \\
\text { liability, assurance, responsiveness and communication and } 13 \text { indica- } \\
\text { tors. } \\
\text { Conclusions indicate DSQ is positively linked with satisfaction of } \\
\text { stakeholders in the supply chain. }\end{array}$ & $\begin{array}{l}\text { - The use of convenience sampling technique is } \\
\text { a limitation of this study. } \\
\text { Data were obtained from } 3 \text { big cities only } \\
\text { which limit the generalization of results. }\end{array}$ \\
\hline $\begin{array}{l}\text { SQ } 25 \\
\text { Gupta and Singh (2017) }\end{array}$ & $\begin{array}{l}\text { - The study extended the earlier model by relating service quality of } \\
\text { five drivers with customer satisfaction and customer loyalty using ANN. } \\
\text { The customer satisfaction and customer loyalty were } 48.75 \% \text { and } \\
29.68 \% \text { which was found to be significant. }\end{array}$ & Structural model is not prepared. \\
\hline
\end{tabular}


It comes out from the literature that the output delivered by employees is a well explored area but fewer studies are seen on the applicability of service quality attributes on the employee function. This study seeks to address this gap existing in SQ literature.

The SERVQUAL pioneered by Parasuraman et al. (1988) is the most extensively used service quality measurement instrument because of the ease of use, possession of a simple structure and capability of generalization (Philip \& Hazlett, 1997). Since the quality of services largely depends on the human behavior, the quality dimensions of the measuring instrument differ in different service settings. For example, "empathy" and "responsiveness" are more significant in health sector whereas "reliability" is important in transportation. Therefore, SERVQUAL dimensions need to be modified in order to suit the particular service settings. Thus, the numbers of dimensions have been changed or items under each dimension modified to suit the particular application (Saleh and Ryan, 1991). Cronin and Taylor (1992) found that 5-dimension structure of SRVQUAL (as proposed by Parasuraman et al. 1988) did not emerge in empirical examinations and proposed SERVPERF scale. Carr (2007) proposed an important limitation of SERVQUAL/SERVPERF scale by stating that it does not include fairness, as one of the salient determinants of the scale, though "fairness in treatment amongst internal customers" is most warranted and should be evaluated in service encounters.

FAIRSERV, in conjunction with SERVPERF, may be suitable for this study, due to its focus on satisfaction and re-patronage intensions. The preliminary questionnaire is on five attributes of SERVPERF scale (i.e. Reliably, Assurance, Tangibles, Empathy and Responsiveness) and "Systematic Fairness" attribute of FAIRSERV model. Taking cues from both existing scales to measure service quality, we have made a modest attempt at designing a new scale based on the combination of the two metrics as shown in Fig. 1.

\section{RATERF- the SQ Determinants}

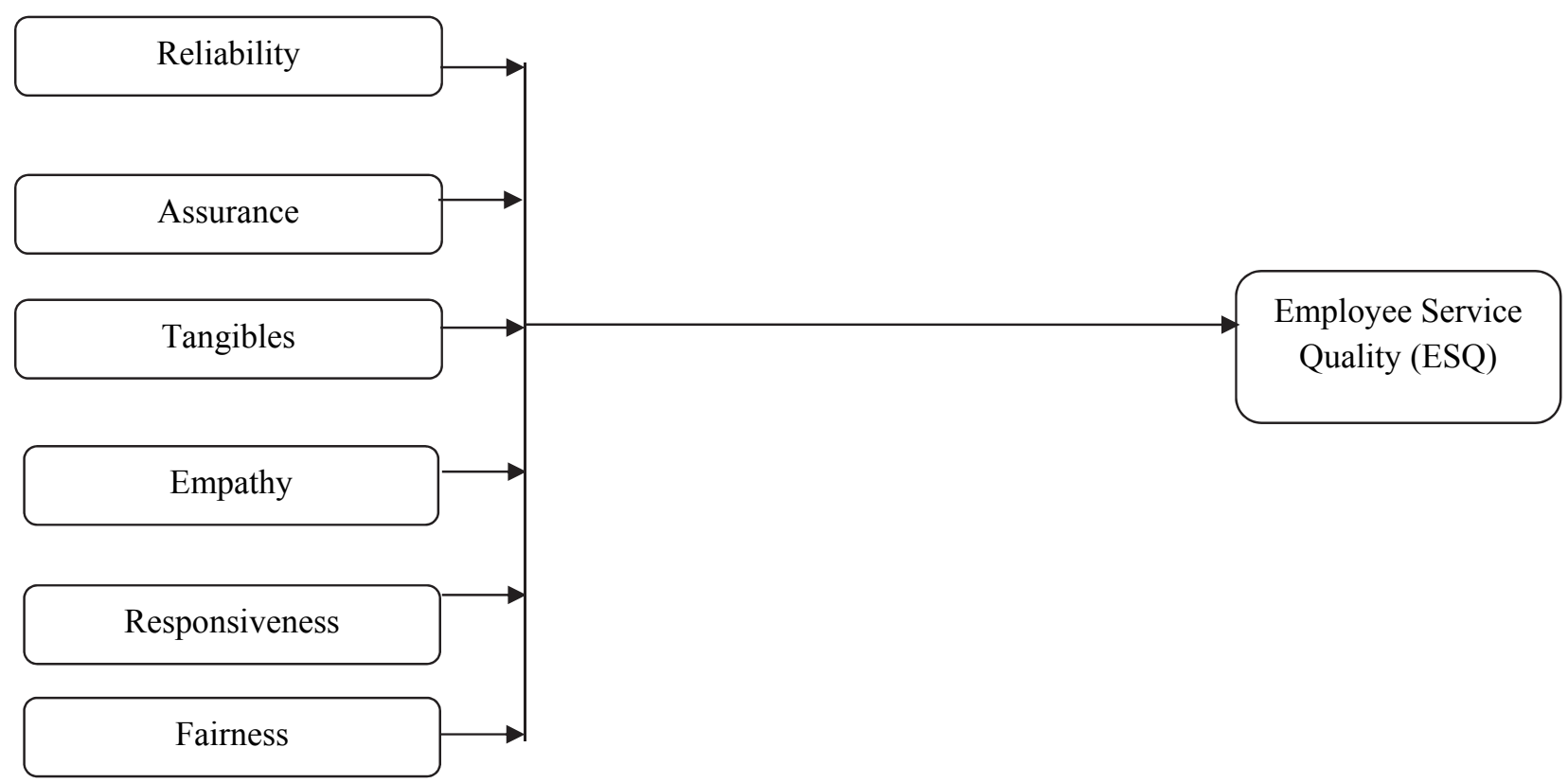

Fig. 1. Relationship between Independent Variables and Dependent Variable

In this study, employee service quality was treated as dependent variable with hybrid model RATERF comprises of six independent or antecedent variables. 


\section{Research methodology}

Fig. 2 shows the research methodology used for the development of the scale for measuring ESQ. A survey was developed (Annexure-1) as narrated in the previous section using SERVQUAL and FAIRSERV scales. The questionnaire was refined after focus group discussion with small-medium manufacturing unis' managers and academicians. The section-A of the questionnaire comprises of 22 indicators related to ESQ and one item measuring overall service quality; whereas the section-B focuses on gathering the demographic information. Before circulation, the questionnaire was authenticated through a pilot study (Robson, 2010) carried out by discussing the questionnaire items with five experts from the industry (at the top/middle management levels) and academicians. Their suggestions thus received were incorporated and questionnaire was revised.

Data was collected by personally visiting the respective units using snowball sampling for making direct contact with professionals and to execute the survey through 'structured interview schedule'. Respondents were asked to enter their perceptions of service quality on 5-point Likert scale.

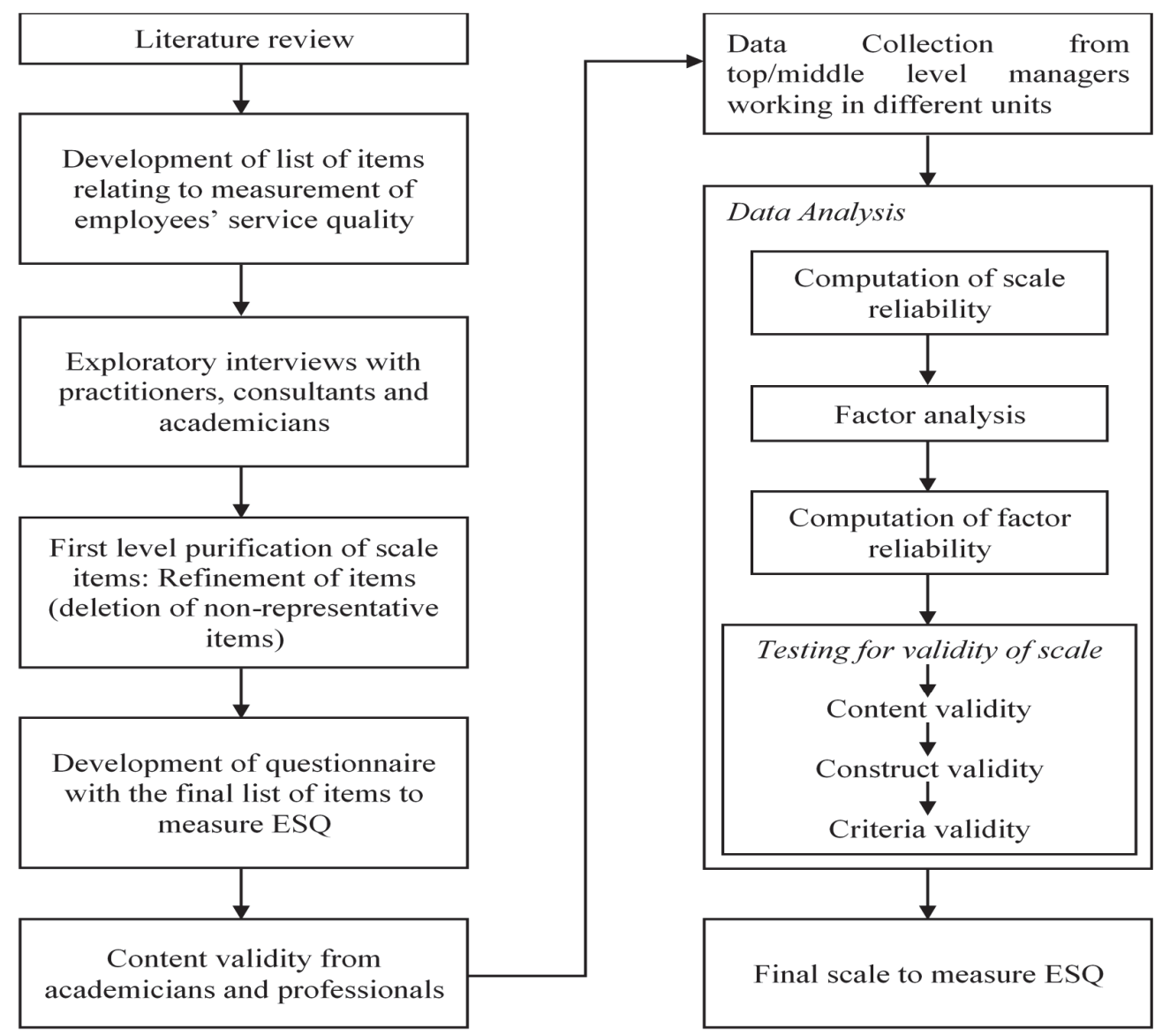

Fig. 2. Research methodology for developing a scale for measuring Employees’ Service Quality

Prior to the commencement of the data collection, introductory e-mails were sent out to plant heads of respective units. Plant heads referred the researcher to the key respondents, who could be contacted for filling-in the questionnaires. Most of the respondents themselves filled-in the questionnaire at the time the researcher approached them, while other respondents kept the questionnaires, and returned them to the researcher in subsequent visits. The purpose of this approach was to enhance the response rate and improve the quality of data. This approach has been endorsed by other scholars in the literature (Flynn et al., 1990; Forza, 2002; Kang \& Bradley, 2002). 
The researcher approached 165 respondents serving in different small-medium manufacturing units and was able to elicit data from 144 respondents, thus fetching a response rate of $87 \%$ which was quite encouraging. This high rate of response may be attributed to involvement and commitment of unit heads of respective units and personal visits by the researcher to collect data. The type of manufacturing activity being carried by the respondent units is shown in Table 2 .

Table 2

Type of product being manufactured by respondent SMEs units $(\mathrm{N}=144)$

\begin{tabular}{lcc}
\hline Type of Manufacturing Unit & Small Scale & Medium Scale \\
\hline Number \& Percentage & $103(72 \%)$ & $41(28 \%)$ \\
\hline Type of Product & & $13(\approx 9 \%)$ \\
\hline Auto Parts & $30(\approx 21 \%)$ & $7(\approx 5 \%)$ \\
Hand Tools & $18(\approx 13 \%)$ & $5(\approx 3 \%)$ \\
Casting Components & $12(\approx 8 \%)$ & $4(\approx 3 \%)$ \\
Valve manufacturing/Casting & $10(\approx 7 \%)$ & $4(\approx 3 \%)$ \\
Rolled Products & $9(\approx 6 \%)$ & $3(\approx 2 \%)$ \\
Machine Tools & $8(\approx 6 \%)$ & $3(\approx 2 \%)$ \\
Sheet Metal Components & $6(\approx 4 \%)$ & $2(\approx 1 \%)$ \\
Fasteners & $6(\approx 4 \%)$ & Nil \\
\hline Multi Products & $4(\approx 3 \%)$ & \\
\hline
\end{tabular}

The demographic distribution of respondents is presented in Table 3. The respondents have been categorized on the basis of number of years of experience, qualifications, and functional area of work. Majority of the respondents belonged to the top and middle management of units including Proprietors, MDs, Unit Heads, Chief Works Managers, GMs, Senior Engineers, Executive Engineers, Heads of different departments \& sections etc. We find that most of the respondents have work experience in the range 2 to 10 years, hold engineering qualification, and work in varied functional units of the organization.

Table 3

Demographic distribution of respondents $(\mathrm{N}=144)$

\begin{tabular}{|c|c|c|c|c|c|c|c|c|}
\hline \multicolumn{3}{|c|}{ Experience } & \multicolumn{3}{|c|}{ Qualification } & \multicolumn{3}{|c|}{ Functional Area of work } \\
\hline Distribution & $\mathbf{n}$ & $\%$ & Distribution & $\mathbf{n}$ & $\%$ & Department & $\mathbf{n}$ & $\%$ \\
\hline $2-5$ years & 32 & 22 & MBA/M.Tech./M.Sc. & 20 & 14 & Procurement/MRP & 23 & 16 \\
\hline $6-10$ years & 49 & 34 & BBA/B.Tech./B.Sc. & 45 & 31 & HR & 64 & 44 \\
\hline $11-15$ years & 30 & 21 & MA/BA/B.Com. & 31 & 22 & Marketing/Sales & 26 & 18 \\
\hline $16-20$ years & 18 & 13 & Technical Diploma & 28 & 19 & Quality Control & 20 & 14 \\
\hline above 20 years & 15 & 10 & Intermediate/below & 20 & 14 & PPC & 11 & 08 \\
\hline
\end{tabular}

\section{Data analysis and results}

Since all the 22 questions to measure employees' service quality (ESQ) are synthesized from the literature; the imperative is first to assess this scale through reliability analysis, EFA, followed by CFA.

\subsection{Reliability Analysis}

The reliability of the management's perception of ESQ was analyzed using Cronbach alpha coefficient. In this analysis, Reliability is assessed by internal consistency method which reflects equivalence, homogeneity and inter-correlation of the items used in a measure. Output of this analysis is provided by IBM SPSS v21 and indicates significantly high reliability of data (Lee et al., 2000) and is depicted in Table 4.

Table 4

Reliability Analysis of Employees' Service Quality scale (22 items)

\begin{tabular}{ll}
\hline Service Quality Measurement & Management's Perception of Employee Service Quality \\
\hline Value of $\boldsymbol{\alpha}$ & 0.904 \\
Finding & Meritorious \\
\hline
\end{tabular}




\subsection{Factor Analysis}

Exploratory Factor Analysis (EFA) of the data is carried out through a sequence of steps. First, Bartlett test of Sphericity is used to verify appropriateness of factor analysis is assessed by analyzing correlation matrix of the data (Hair et al., 2010). Simultaneously, assessment of sampling adequacy $(\mathrm{N}=144$, in this case) is judged by Kaiser-Meyer-Olkin (KMO) statistics which ranges from 0 to 1 . The KMO value of above 0.6 is considered significant and indicates suitability of factor analysis. The score of Bartlett test of Sphericity and the KMO value is provided by SPSS v2 1 and is depicted in Table 5. The results are significant, thus, providing indication of suitability of factor analysis (Hair et al., 2010).

\section{Table 5}

KMO for Sampling Adequacy and Bartlett's Test of Sphericity

\begin{tabular}{llc}
\hline \multicolumn{2}{l}{ KMO Measure for Sampling Adequacy } & .819 \\
\hline \multirow{3}{*}{ Bartlett's Test of Sphericity } & Approx. Chi-Square & 2221 \\
& df & 231 \\
& Sig. & .000 \\
\hline
\end{tabular}

EFA is conducted using the Principle Component Analysis (PCA) with Kaiser Normalization (Eigen values greater than 1) and varimax rotation procedure. The objective is to summarize the information asked in the 22 questions into a smaller set of new attributes that attempted to bring out the constructs for measurement of service quality offered by employees. This resulted in the extraction of five factors, explaining 73.551 per cent of the variance. The individual factors explained 18.226, 17.114, 14.703, 14.341 and 9.166 percent of the variance respectively. These factor loadings are consistent with the suggested factor structure of the scale. Output of exploratory factor analysis using SPSS v21 is presented in Table 6 .

\section{Table 6}

Communalities, Factor Structure and Loadings for Items of Scale for measuring ESQ Principal Components Method with Varimax Rotation Loading $\geq .55^{*}$

\begin{tabular}{|c|c|c|c|c|c|c|c|}
\hline \multirow[t]{2}{*}{ S. No. } & \multirow[t]{2}{*}{ Factors and Associated Items } & \multirow[t]{2}{*}{ Communalities } & \multicolumn{5}{|c|}{ Factor Structure \& loadings } \\
\hline & & & F1 & F2 & F3 & F4 & F5 \\
\hline \multicolumn{8}{|c|}{ Dependability (F1) } \\
\hline 1. & Employees possess knowledge, expertise \& skills & .512 & .700 & & & & \\
\hline 2. & Employees deliver high quality products & .809 & .867 & & & & \\
\hline 3. & Employees possess technical competence & .633 & .739 & & & & \\
\hline 4. & Employees deliver correct quantity in right time & .660 & .760 & & & & \\
\hline 5. & Employees are honest and trustworthy & .654 & .740 & & & & \\
\hline 6. & Employees maintain confidentiality & .740 & .778 & & & & \\
\hline \multicolumn{8}{|c|}{ Agility (F2) } \\
\hline 7. & Employees are innovative in operations & .677 & & .876 & & & \\
\hline 8. & Employees are flexible \& adaptive to change & .685 & & .704 & & & \\
\hline 9. & Employees share operational information & .762 & & .840 & & & \\
\hline 10. & Employees provide timely feedback & .624 & & .877 & & & \\
\hline 11. & Employees are courteous \& have positive attitude & .781 & & .882 & & & \\
\hline \multicolumn{8}{|c|}{ Professionalism (F3) } \\
\hline 12. & Employees have willingness to work for the unit & .848 & & & .781 & & \\
\hline 13. & Employees fix quick solutions to complaints & .814 & & & .861 & & \\
\hline 14. & Employees demand just wage \& salary & .691 & & & .812 & & \\
\hline 15. & Employees demand fair terms \& conditions & .748 & & & .837 & & \\
\hline \multicolumn{8}{|c|}{ Understanding (F4) } \\
\hline 16. & Employees use right tools \& equipment & .804 & & & & .792 & \\
\hline 17. & Employees make proper use of physical facilities & .788 & & & & .902 & \\
\hline 18. & Employees understand requirements of the firm & .789 & & & & .859 & \\
\hline 19. & Employees care for convenience of co-workers & .737 & & & & .745 & \\
\hline \multicolumn{8}{|c|}{ Assurance (F5) } \\
\hline 20. & Employees are prompt in action & .836 & & & & & .772 \\
\hline 21. & Employees use latest ICT tools & .754 & & & & & .844 \\
\hline 22. & Employees have strong market reputation & .834 & & & & & .690 \\
\hline \multicolumn{3}{|c|}{ Reliability (Cronbach Alpha ${ }^{\#}$ value) of identified factors } & .894 & .910 & .913 & .900 & .754 \\
\hline
\end{tabular}


Based on the subjective opinion of the researcher in consultation with a group of experts, the factors were named as: Dependability, Agility, Professionalism, Understanding, and Assurance. The communalities express the proportion of the variance of the 22 items extracted by the five factors of the scale. All the items have significant communalities (not less than 0.50) (Hair et al., 2010). The factor-item loadings represent the correlations between each item with their underlying factors. All the items have significant factor loadings (not less than 0.55) (Pitt et al., 1995). Internal reliability of the items of the various factors of the scale is examined using the Cronbach alpha coefficients. This approach is in line with that of Bagozzi \& Yi (1988). In this analysis, reliability score for each factor ranges from $75.4 \%$ to $91.3 \%$ as shown in table 5 and hence is acceptable (Nunnally \& Bernstein, 1978).

\subsection{Confirmatory Factor Analysis (CFA)}

CFA is undertaken to further validate the scale for measuring employees' service as perceived by management/executive/supervisor. CFA confirms the factor structure by testing the fit of CFA model. CFA model is run using SPSS AMOS v21, for 5 individual factors with respective items. Based on the methodology of Sureshchandar et al. (2002) and Bienstock et al. (1997), the model fit was examined for each factor. Table 7 shows the key model fit indices for the individual factors.

Table 7

Key fit Indices for measurement model of SESQSC

\begin{tabular}{lcccccc}
\hline \multicolumn{1}{c}{ Factors } & $\begin{array}{c}(\boldsymbol{\chi} \mathbf{2}) / \mathbf{d f}= \\
\mathbf{C m i n} / \mathbf{d f}\end{array}$ & RMR & GFI & NFI & CFI & RMSEA \\
\hline F1: Dependability & 1.337 & .025 & .981 & .985 & .996 & .077 \\
F2: Agility & .051 & .002 & 1.000 & 1.000 & 1.000 & .000 \\
F3: Professionalism & 1.777 & .012 & .988 & .991 & .996 & .074 \\
F4: Understanding & 1.739 & .008 & .989 & .990 & .996 & .072 \\
F5: Assurance & --- & .000 & 1.000 & 1.000 & 1.000 & -- \\
\hline
\end{tabular}

All the GFI values are above 0.9 , which clearly provides validation of individual factors of CFA model (Hair et al., 2010).

\subsubsection{Scale Purification}

In order to develop the measurement scale, the covariance matrix between the five identified factors was created as shown in Fig. 3.

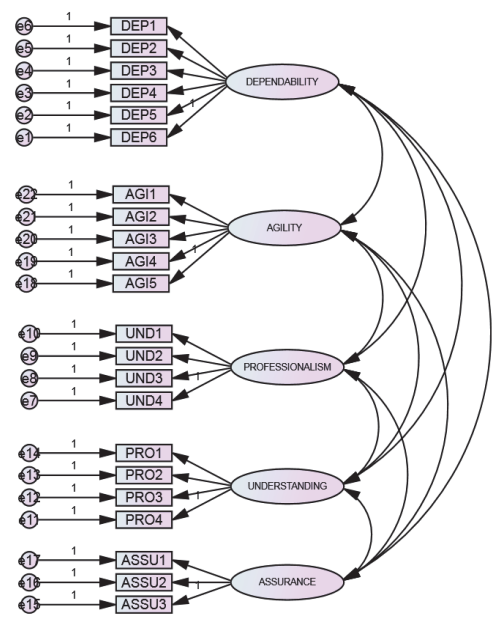

Fig. 3. Theoretical framework for development of Employee Service Quality Scale

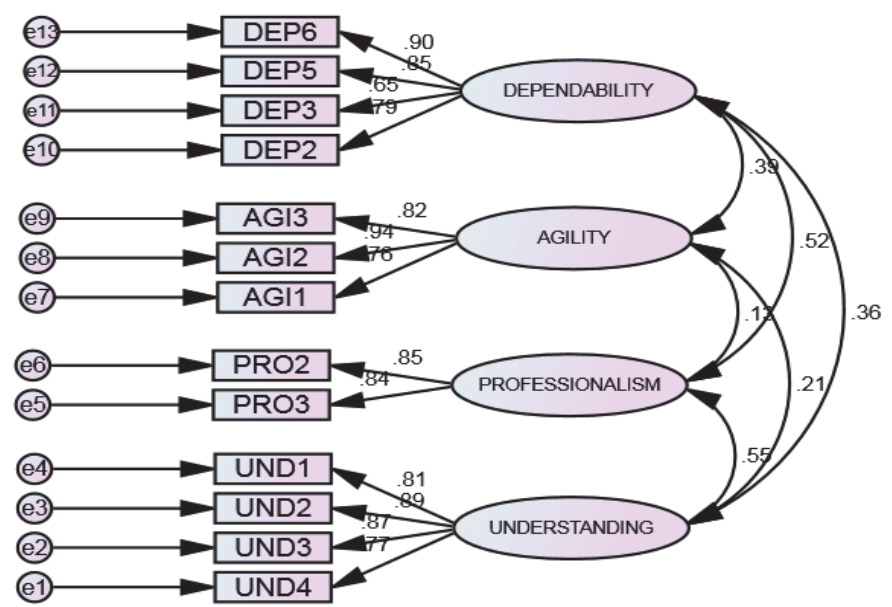

Fig. 4. CFA Model Development for measuring Employees' Service Quality 
Five iterations runs of CFA were performed to obtain satisfactory goodness of fit indices. During this process, one dimension viz. Assurance, was completely dropped. In total, 9 out of an initial 22 items were deleted. The nine items deleted due to low variance were:

- employees possess knowledge, expertise \& skills;

- employees maintain confidentiality;

- employees provide timely feedback;

- employees have positive attitude towards the unit;

- employees have willingness to work for the unit;

- employees demand fair terms \& conditions;

- employees are prompt in action;

- employees use latest ICT tools; and

- employees have strong market reputation

The final model consisting of 4 factors and 13 sub-factors is depicted in Fig. 4.

\subsubsection{Model Fit}

Various goodness-of-fit indices are obtained by running the model using AMOS v 21. The Normed Chi-square value for this model is 1.748 , which represents a good fit. The acceptable ratio of Normed Chi-square value is up to 3 or even 5 (Bollen, 1989; Tanaka, 1987). The Goodness-of-Fit Index (GFI), the Comparative Fit Index (CFI) and the Normed Fit Index (NFI) values for this model were 0.907, 0.958 , and 0.908 respectively. The RMSEA value of 0.072 indicates a reasonable fit. From these values it is inferred that model represents an adequate fit.

\subsubsection{Interpretation of Factor Structure}

The four factors specify service quality delivered by employees to their respective manufacturing units. The total variance explained by the four factors in the second round of factor analysis was 73.878 percent in comparison to a total variance of 73.551 percent, explained by the five factors in the first round of factor analysis. The results suggested that the four factors (dimensions) explain service quality of employees in small-medium manufacturing in a better manner. Thus, the final model of employees' service quality has four dimensions, as the fifth dimension has been removed. The first factor labeled as "Dependability (ability to perform error free, and reliable service with integrity)" accounted for 21.025 percent of the variance. The four items defining this factor, with factor loadings ranging from 0.867 to 0.740 included the items namely, "deliver high quality products", "deliver correct quantity in right time", "polite and courteous behaviour and "honest and trustworthy". The factor draws relevance from the work of Parasuraman et al. (1985); Grönroos (1988); Drew and Karwan (1994); Li et al. (2006) and Saraph et al. (2009) in literature.

The second factor labeled as "Agility (ability to respond to sudden changes in requirements and external disruptions in an efficient manner)" accounted for 19.683 percent of the variance. It depicts the effectiveness and flexibility of employees in handling daily transactions with co-workers in different functions and at different levels. This attribute not only helps in building an efficient work environment but also helps to deliver better service quality in every interaction with internal customers within the unit. The three items describing this factor, with factor loadings ranging from 0.704 to 0.876 , included the items namely, "timely feedback," "Innovativeness in operations," and "flexible and adaptive to change." The factor has relevance with Parasuraman et al. (1985); and Dagger et al. (2007); Sachdev and Verma, 2004; Singh et al. (2006); Ganguli et al. (2010); and Izogo et al. (2015) from literature.

The third factor labeled as "Professionalism (the keenness and enthusiasm of employees for serving the unit and value they place on the operations performed by them)" accounted for 16.844 percent of the 
variance. The two items defining this factor, with factor loadings 0.861 and 0.812 , included the items namely, "fixing quick solutions to complaints" and "demand just wage and salary." The factor bears relevance with Parasuraman et al. (1985); Schvaneveldet et al. (1991); Mersha and Adlakha (1992); Luo and Liu (2007); Lu and Nepal (2009); and Tsang et al. (2015) from marketing literature.

The fourth factor labeled as "Understanding (the knowledge and competence of employees regarding internal working of the unit)" accounted for 16.325 percent of the variance. The four items defining this factor, with factor loadings ranging from 0.902 to 0.745 , included the items namely, "use of right tools and equipment", "making appropriate use of physical facilities", "understanding requirements of the unit," and "care for convenience of co-workers." The factor bears relevance with Parasuraman et al. (1985); Lehtinen and Lehtinen (1991); Ghobadian et al. (1994); Ekinci et al. (2003); Droege et al. (2009); Melton \& Hartline (2010); Fischer et al., 2010; Gremyr et al. (2014) ; Kindstorm \& Kowalkowski (2015), and Zhu \& Zolkiewski (2016) from marketing literature.

\subsection{Descriptive Statistics}

Descriptive statistics in the form of mean scores and SDs of 13 items finally used in the revised scale with their underlying factors are calculated using MS Excel and are depicted in Table 8.

\section{Table 8}

Summary Statistics of Factor Scores of Employees' Service Quality $(\mathrm{N}=144)$

\begin{tabular}{|c|c|c|c|c|}
\hline \multirow[t]{2}{*}{ Factors underlying Extrinsic Service Quality } & \multirow{2}{*}{\multicolumn{2}{|c|}{$\begin{array}{cc}\text { Mean } & \begin{array}{c}\text { Standard } \\
\text { Deviation }\end{array} \\
\text { Measurement on } \\
\text { 5-point Likert Scale }\end{array}$}} & \multicolumn{2}{|c|}{ Overall Score of Factor } \\
\hline & & & Mean & $\begin{array}{l}\text { Standard } \\
\text { Deviation }\end{array}$ \\
\hline \multicolumn{5}{|l|}{$\begin{array}{l}\text { Scores of Employees'Service Quality } \\
\text { Dependability }\end{array}$} \\
\hline Employees deliver high quality products & 2.86 & 0.850 & 2.89 & 0.882 \\
\hline Employees possess technical competence & 2.69 & 0.865 & & \\
\hline Employees deliver correct quantity in right time & 3.04 & 0.876 & & \\
\hline Employees are honest and trustworthy & 2.98 & 0.935 & & \\
\hline \multicolumn{5}{|l|}{ Agility } \\
\hline Employees are innovative in operations & 2.33 & 0.860 & 2.24 & $\mathbf{0 . 8 5 0}$ \\
\hline Employees are flexible $\&$ adaptive to change & 2.26 & 0.916 & & \\
\hline Employees share operational information & 2.13 & 0.774 & & \\
\hline \multicolumn{5}{|l|}{ Professionalism } \\
\hline Employees fix quick solutions to complaints & 4.04 & 0.958 & 4.05 & 0.944 \\
\hline Employees demand just wage \& salary & 4.05 & 0.929 & & \\
\hline \multicolumn{5}{|l|}{ Understanding } \\
\hline Employees use right tools \& equipment & 3.44 & 0.719 & 3.49 & 0.722 \\
\hline Employees make proper use of physical facilities & 3.43 & 0.708 & & \\
\hline Employees understand requirements of the firm & 3.44 & 0.751 & & \\
\hline Employees care for convenience of co-workers & 3.65 & 0.710 & & \\
\hline
\end{tabular}

\subsection{Validity of Construct}

\section{a. Face Validity}

Face validity is assessed by looking at the measures 'on-its-face', which give a good reflection of employee service quality (Trochim, 2007).

\section{b. Content Validity}

Content validity of the questionnaire items is satisfactorily assessed by discussions with scholars, insights derived from the literature, and the researcher's own knowledge (Trochim, 2007). Subsequent refinement of this scale was ensured through focus group discussion with representatives from smallmedium manufacturing units. The instrument thus has strong content validity. 


\section{c. Construct Validity}

Construct validity is assessed through following three steps:

i. $\quad$ Unidimensionality: As stated by Bollen and Ting (1993), "CFI compares the proposed model with a null model assuming that there are no relationships between the measures". CFA model emerged in figure 4 indicates CFI value (0.958) which implies a strong unidimensionality (Bollen and Ting, 1993; Byrne, 1994).

ii. Convergent Validity: As stated by Ahire et al. (1996), "Convergent validity measures the extent to which different approaches to measuring a construct produces the same results. A value of 0.60 or higher for all factor loadings in CFA model developed demonstrates strong convergent validity". Since, in the CFA model developed in figure 4, all the factor loadings ranged from 0.74 to 0.94 so all items in the scale developed have strong convergent validity.

iii. Discriminant Validity: As stated by Bagozzi et al. (1991), "Discriminant validity measures the degree to which a construct and its indicators are different from another construct and its indicators". For DV to hold, "square root of the average variance extracted for a given construct, should be greater than the absolute value of the standardized correlation of the given construct with any other construct in the analysis (Fornell and Larcker, 1981)".

The square root of AVE for each of the factor is shown in the diagonal cells, and the Correlation Coefficient of a factor with the other factors is shown in the non-diagonal cells of the table 9. The square root of AVE for each of the factors was greater than the Correlation Coefficient of that factor with the other factors, and this supported the discriminant validity of the scale.

Table 9

Results of Discriminant Validity for the scale for measuring Employee Service Quality

\begin{tabular}{ccccc}
\hline & Dependability & Agility & Professionalism & Understanding \\
\hline Dependability & $\mathbf{0 . 8 4 5}$ & & & \\
Agility & 0.506 & $\mathbf{0 . 7 8 3}$ & & \\
Professionalism & 0.128 & 0.390 & $\mathbf{0 . 8 4 0}$ & \\
Understanding & 0.547 & 0.359 & 0.208 & 0.835 \\
\hline
\end{tabular}

The $\sqrt{A V E}$ is depicted in the diagonal cells and the correlation in other cells

\section{d. Predictive Validity}

As stated by Nunnally \& Bernstein (1978), "Predictive validity is established when a criterion external to the measurement instrument is correlated with the factor structure". The predictive validity of the four dimensions of ESQ was measured by finding the correlation of each one of them with mean scores of overall employees' service quality (OESQ) (being an external criteria) using Pearson correlation. All the correlation coefficients were positive and significant at a significance level of 0.05 . This assured the predictive validity of the newly developed scale. The results of correlation analysis are shown in the Table 10.

Table 10

Results of correlation between dimensions and overall employees' service quality

\begin{tabular}{cc}
\hline Dimension & Correlation with overall employees' service quality (OESQ) \\
\hline Dependability & $.717^{*}$ \\
Agility & $.507^{*}$ \\
Professionalism & $.567^{*}$ \\
Understanding & $.596^{*}$ \\
\hline
\end{tabular}

* Correlation is significant at the 0.05 level (2-tailed).

\subsection{Relative importance of factors of scale for measuring Employee Service Quality}

To bring out the order of importance of four dimensions comprising the scale for measuring ESQ, regression analysis was conducted by taking the overall employee service quality (OESQ) ratings as 
dependent variable and the mean scores on the four factors as independent variables. The standardized coefficient beta $(\beta)$ of the individual dimension represented their importance (Parasauraman et al., $1985,1988)$ as presented in Table 11.

\section{Table 11}

Regression results for relative importance of dimensions of scale

\begin{tabular}{lcccc}
\hline \multicolumn{1}{c}{ Independent variables } & $\mathbf{R}^{2} /$ Sig. & Beta $(\boldsymbol{\beta})$ & Sig. & Order of importance \\
\hline Dependability & $0.734 / 0.000$ & 0.438 & 0.000 & $\mathbf{1}$ \\
Professionalism & & 0.309 & 0.000 & $\mathbf{2}$ \\
Understanding & & 0.255 & 0.000 & $\mathbf{3}$ \\
Agility & & 0.188 & 0.001 & $\mathbf{4}$ \\
\hline
\end{tabular}

Constant :0.204, $\mathrm{t}=0.046($ Sig. $=0.027)$; Dependent variable: overall employees' service quality

The results clearly show significance of overall regression model $(F=95.965, p<0.00)$, with $73 \%$ of the variance in employees' service quality explained by independent variables. The significant factors that remained in the equation in the overall service quality and are shown in order of their importance based on $\beta$ co-efficient. Higher the standardized $\beta$ co-efficient, the more the factor contributes to explaining dependable variable (Lee et al., 2000). The factor 'Dependability' emerges to be the most important dimension, with $\beta$ coefficient $=0.438$ followed by 'Professionalism' $(\beta=0.309)$, 'Understanding' $(\beta=0.255)$ and 'Agility' to be least important $(\beta=0.188)$.

\section{Significance of the results}

This study has shown how the scale was built and expressed its usefulness for the managers of smallmedium manufacturing units. Figure 5 presents typical benefits gained by monitoring and control of dimensions of scale. Also, the individual benefits of each dimension are highlighted. Once developed, the scale for measuring Employees' Service Quality could be used by managers in several ways as:

1. The insights provided by this study can help managers and researchers in further understanding the service quality issues relating to human factor in small-medium manufacturing units.

2. The scale yields four useful determinants to measure employees' service quality offered to the manufacturing unit viz. Dependability, Agility, Professionalism, and Understanding. The total scale can be obtained by adding the scores on individual dimensions.

3. The scores on individual sub-dimensions indicate suggestions for improvements to managers along those areas. The scale can also be used as a diagnostic tool for identifying poor and/or excellent performance to benchmark across multiple departments within a single manufacturing unit. Furthermore, any of these situations can also be compared across time.

4. Based on performance assessment using these scales, an incentive or reward system can be proposed to reward timely production, quickness in resolving complaints, innovation, and agility exhibited by employees.

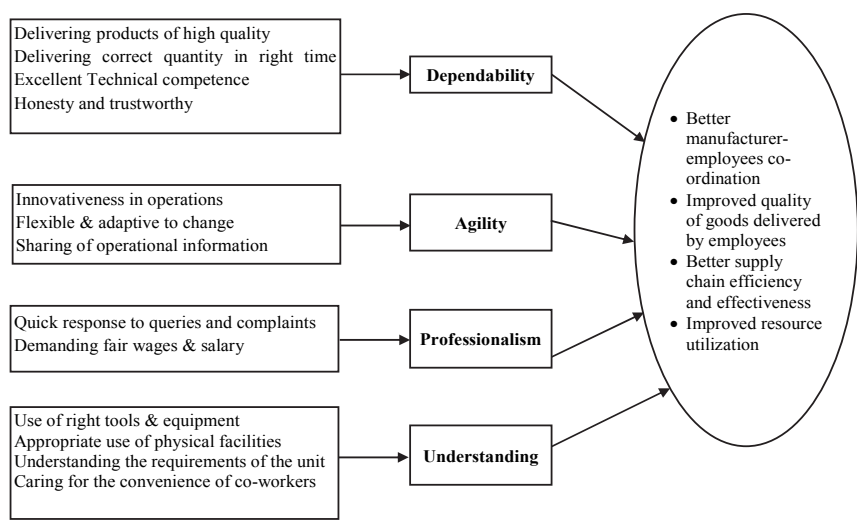

Fig. 5. Typical benefits of Employee service quality 


\section{Conclusion}

In this study, Service quality has been operationalized contextually to bring out the role of services delivered by employees of small-medium manufacturing units in internal service encounters. The hypothesized RATERF scale has revealed four SQ attributes of employee service quality (ESQ) in unit's processes and operations viz. Dependability, Agility, Professionalism, and Understanding. The factors churned out using factor analysis, however differ from the two most popular SQ measurement tools, i.e. SERVQUAL model (PZB, 1985, 1988) as well as FAIRSERV scale (Carr, 2007) used in this particular study. Thus, the study has proposed a new scale, using inputs from literature and practitioners of small-medium manufacturing enterprises.

The findings of this study are in alignment with those obtained by Ahmad et al. (2009); Rodrigues et al. (2011); Prakash (2014) and Parmata (2016). The proposed model embodies relationship among variables defined to co-create value for both provider and receiver and suggests facilitate planning and implementing of quality improvement programs towards the appraisal and performance evaluation of HR function in the organizations under study. It may be concluded that ESQ is a continuous journey to a manufacturing unit's success and will act as an essential step in the enhancement of HR management initiatives.

\section{Limitations \& Future scope}

The results should, however, be interpreted by keeping in mind certain limitations. The interview schedule was conducted on the top/middle management of manufacturing units in northern India. The data size of 144 is limited to obtain a generalized conclusion. This study does not go beyond "ESQ" as the additive parameter of SQ attributes and doesn't link ESQ dimensions with employee productivity and competitiveness. Further, a strong need is realized for the empirical research linking this to the manufacturing unit's performance.

This research, however presents a rich agenda for future researchers. The ESQ scale thus developed can be extended by SME managers to evaluate and control internal service practices at various other echelons including employees of suppliers and distributors in the supply chain. Future researchers can replicate this study with a larger and randomized sample collected from across India. Another area of interest would be the use of 7-point Likert scale rather than 5-point Likert scale for measurement of service quality items and inferring their suitability. Instead of using un-weighted performance only measure, it would be interesting to use the weighted versions of service quality scale, and bring out a comparison.

ESQ can also be used at different periods of time to track the evaluation of service quality delivery. Further, a System Dynamics simulation may be performed to study the influence of each of the RATERF attributes on ESQ. The model may be validated based on the empirical study of this research. Traditionally, service quality delivery has been overlooked in such units with an understanding that transaction-specific, "hire and fire at will" opportunistic approach may work best for them. Specifically, managers should appreciate relationships with employees and take necessary actions to improve communications, and solve employees-related problems to retrieve the best out of them. Finally, this study is an attempt to understand employees' service quality and highlight the potential area for future research.

\section{References}

Ahire, S. L., Golhar, D. Y., \& Waller, M. A. (1996). Development and validation of TQM implementation constructs. Decision sciences, 27(1), 23-56.

Ahmad, N., Usman Awan, M., Raouf, A., \& Sparks, L. (2009). Development of a service quality scale for pharmaceutical supply chains. International Journal of Pharmaceutical and Healthcare Marketing, 3(1), 26-45. 
Bagozzi, R. P., \& Yi, Y. (1988). On the evaluation of structural equation models. Journal of the Academy of Marketing Science, 16(1), 74-94.

Bagozzi, R. P., Yi, Y., \& Phillips, L. W. (1991). Assessing construct validity in organizational research. Administrative Science Quarterly, 421-458.

Behara, R. S., Fisher, W. W., \& Lemmink, J. G. (2002). Modelling and evaluating service quality measurement using neural networks. International Journal of Operations \& Production Management, 22(10), 1162-1185.

Bienstock, C. C., Mentzer, J. T., \& Bird, M. M. (1997). Measuring physical distribution service quality. Journal of the Academy of Marketing Science, 25(1), 31.

Bollen, K. A. (1989). Structural Equations with Latent Variables.

Bollen, K. A., \& Ting, K. F. (1993). Confirmatory tetrad analysis. Sociological methodology, 147-175.

Bowen, D. E., \& Schneider, B. (1988). Services marketing and management-implications for organizational-behavior. Research in Organizational Behavior, 10, 43-80.

Bowersox, D. J., Closs, D. J., \& Stank, T. P. (1999). 21 st century logistics: making supply chain integration a reality.

Brady, M. K., \& Cronin Jr, J. J. (2001). Some new thoughts on conceptualizing perceived service quality: a hierarchical approach. Journal of Marketing, 65(3), 34-49.

Bustinza, O. F., Bigdeli, A. Z., Baines, T., \& Elliot, C. (2015). Servitization and competitive advantage: the importance of organizational structure and value chain position. Research-Technology Management, 58(5), 53-60.

Byrne, B. M. (1994). Structural equation modeling with EQS and EQS/Windows. Thousand Oaks, Califomia: Sage Publications.

Carr, C. L. (2007). The FAIRSERV model: Consumer reactions to services based on a multidimensional evaluation of service fairness. Decision Sciences, 38(1), 107-130.

Cronin Jr, J. J., \& Taylor, S. A. (1992). Measuring service quality: a reexamination and extension. The Journal of Marketing, 55-68.

Dabholkar, P. A., Shepherd, C. D., \& Thorpe, D. I. (2000). A comprehensive framework for service quality: an investigation of critical conceptual and measurement issues through a longitudinal study. Journal of Retailing, 76(2), 139-173.

Dagger, T. S., Sweeney, J. C., \& Johnson, L. W. (2007). A hierarchical model of health service quality: scale development and investigation of an integrated model. Journal of Service Research, 10(2), 123-142.

Das, S., \& Pandit, D. (2015). Determination of level-of-service scale values for quantitative bus transit service attributes based on user perception. Transportmetrica A: Transport Science, 11(1), 1-21.

Dodson, R. L. (1991). Speeding the way to total quality. Training \& Development, 45(6), 35-43.

Drew R. L., \& Karwan, K. R. (1994). Prioritizing the dimensions of service quality: an empirical investigation and strategic assessment. International Journal of Service Industry Management, 5(4), 39-52.

Droege, H., Hildebrand, D., \& Heras Forcada, M. A. (2009). Innovation in services: present findings, and future pathways. Journal of Service Management, 20(2), 131-155.

Ekinci, Y., Prokopaki, P., \& Cobanoglu, C. (2003). Service quality in Cretan accommodations: marketing strategies for the UK holiday market. International Journal of Hospitality Management, 22(1), 47-66.

Fischer, T., Gebauer, H., Gregory, M., Ren, G., \& Fleisch, E. (2010). Exploitation or exploration in service business development? Insights from a dynamic capabilities perspective. Journal of Service Management, 21(5), 591-624.

Flynn, B. B., Sakakibara, S., Schroeder, R. G., Bates, K. A., \& Flynn, E. J. (1990). Empirical research methods in operations management. Journal of Operations Management, 9(2), 250-284.

Fornell, C., \& Larcker, D. F. (1981). Evaluating structural equation models with unobservable variables and measurement error. Journal of Marketing Research, 39-50.

Forza, C. (2016). Surveys. In Research Methods for Operations Management (pp. 95-180). Routledge. 
Frost, F. A., \& Kumar, M. (2000). INTSERVQUAL-an internal adaptation of the GAP model in a large service organisation. Journal of Services Marketing, 14(5), 358-377.

Gandhi, S., Sachdeva, A \& Gupta, A. (2018). Distributor service quality in Indian SMEs: A bi-directional customer perspective. Uncertain Supply Chain Management, 6(4), 335-356.

Ganguli, S., \& Roy, S. K. (2010). Service quality dimensions of hybrid services. Managing Service Quality: An International Journal, 20(5), 404-424.

George, W. R. (1990). Internal marketing and organizational behavior: A partnership in developing customer-conscious employees at every level. Journal of Business Research, 20(1), 63-70.

Ghobadian, A., Speller, S., \& Jones, M. (1994). Service quality: concepts and models. International Journal of Quality \& Reliability Management, 11(9), 43-66.

Gremyr, I., Witell, L., Löfberg, N., Edvardsson, B., \& Fundin, A. (2014). Understanding new service development and service innovation through innovation modes. Journal of Business \& Industrial Marketing, 29(2), 123-131.

Grönroos, C. (1984). A service quality model and its marketing implications. European Journal of marketing, 18(4), 36-44.

Grönroos, C. (1988). Service quality: The six criteria of good perceived service. Review of business, 9(3), 10.

Grönroos, C. (1990). Service management and marketing: Managing the moments of truth in service competition. Lexington books.

Gupta, T. K., \& Singh, V. (2017). Measurement of service quality of automobile organisation by artificial neural network. International Journal of Management Concepts and Philosophy, 10(1), 3253.

Gupta, T., \& Singh, V. (2015). Fuzzy graph theoretic approach to compare the factors affecting the service quality of distributors. International Journal of Applied Engineering Research, 10(78), 182186.

Hair Jr, J. F., Black, W. C., Babin, B. J., Anderson, R. E., \& Tatham, R. L. (2010). SEM: An introduction. Multivariate data analysis: A global perspective, 629-686.

Hallowell, R., Schlesinger, L. A., \& Zornitsky, J. (1996). Internal service quality, customer and job satisfaction: Linkages and implications for management. People and Strategy, 19(2), 20.

Hazra, S. G., \& Srivastava, K. B. (2009). Impact of service quality on customer loyalty, commitment and trust in the Indian banking sector. IUP Journal of Marketing Management, 8(3/4), 74.

Kang, G. D. (2006). The hierarchical structure of service quality: integration of technical and functional quality. Managing Service Quality: An International Journal, 16(1), 37-50.

Kang, G. D., \& James, J. (2004). Service quality dimensions: an examination of Grönroos's service quality model. Managing Service Quality: An International Journal, 14(4), 266-277.

Kang, H., \& Bradley, G. (2002). Measuring the performance of IT services: An assessment of SERVQUAL. International Journal of Accounting Information Systems, 3(3), 151-164.

Kelkar, M. (2010). SERVDIV: A Vedic approach to measurement of service quality. Services Marketing Quarterly, 31(4), 420-433.

Kindström, D., \& Kowalkowski, C. (2015). Service Driven Business Model Innovation: Organizing the Shift from a Product-Based to a Service-Centric Business Model.

Kuo, H. P., \& Tsai, Y. C. (2009). The relationships between service attributes and behavioral intentions for the real estate brokerage. The Business Review (Cambridge), 14(1), 272-279.

Lee, H., Lee, Y., \& Yoo, D. (2000). The determinants of perceived service quality and its relationship with satisfaction. Journal of Services Marketing, 14(3), 217-231.

Lehtinen, U., \& Lehtinen, J. R. (1991). Two approaches to service quality dimensions. Service Industries Journal, 11(3), 287-303.

Lev, B. (2004). Sharpening the intangibles edge. Harvard business review, 6, 109-116.

Li, S., Ragu-Nathan, B., Ragu-Nathan, T. S., \& Rao, S. S. (2006). The impact of supply chain management practices on competitive advantage and organizational performance. Omega, 34(2), 107-124.

Lu, J., \& Nepal, S. K. (2009). Sustainable tourism research: An analysis of papers published in the Journal of Sustainable Tourism. Journal of Sustainable Tourism, 17(1), 5-16. 
Luo, Z. P., \& Liu, C. (2007). An Analysis of Service Quality of Front Office in Hotels and Customer Satisfaction—A Case Study of Novotel Peace Beijing Hotel [J]. Tourism Tribune, 3, 015.

Magidson, J., \& Polcha, A. E. (1992). Creating market economies within companies. Journal of Business Strategy, 13(3), 39-44.

Melton, H. L., \& Hartline, M. D. (2010). Customer and frontline employee influence on new service development performance. Journal of Service Research, 13(4), 411-425.

Mersha, T., \& Adlakha, V. (1992). Attributes of service quality: the consumers' perspective. International journal of service industry management, 3(3), 34-45.

Nix, N. (2001). Customer service in supply chain management context. Supply Chain Management, CA: Sage Publications, Beverly Hills.

Nunnally, J. C., \& Bernstein, I. H. (1978). Psychometric theory.

Olorunniwo, F., \& Hsu, M. K. (2006). A typology analysis of service quality, customer satisfaction and behavioral intentions in mass services. Managing Service Quality: An International Journal, 16(2), 106-123.

Olorunniwo, F., Hsu, M. K., \& Udo, G. J. (2006). Service quality, customer satisfaction, and behavioral intentions in the service factory. Journal of Services Marketing, 20(1), 59-72.

Parasuraman, A., Zeithaml, V. A., \& Berry, L. L. (1985). A conceptual model of service quality and its implications for future research. The Journal of Marketing, 41-50.

Parasuraman, A., Zeithaml, V. A., \& Berry, L. L. (1988). SERVQUAL: A multiple-item scale for measuring consumer perception of service quality, Journal of Retailing, 64(1), 12.

Parasuraman, A., Zeithaml, V. A., \& Malhotra, A. (2005). ES-QUAL: A multiple-item scale for assessing electronic service quality. Journal of Service Research, 7(3), 213-233.

Park, J. W., Robertson, R., \& Wu, C. L. (2005). Investigating the effects of airline service quality on airline image and passengers' future behavioural intentions: findings from Australian international air passengers. Journal of Tourism Studies, 16(1), 2.

Parmata, U. M. D. (2016). Measuring service quality in pharmaceutical supply chain-distributor's perspective. International Journal of Pharmaceutical and Healthcare Marketing, 10(3), 258-284.

Philip, G., \& Hazlett, S. A. (1997). The measurement of service quality: a new PCP attributes model. International Journal of Quality \& Reliability Management, 14(3), 260-286.

Pitt, L. F., Watson, R. T., \& Kavan, C. B. (1995). Service quality: a measure of information systems effectiveness. MIS quarterly, 173-187.

Prakash, A., Jha, S. K., \& Kallurkar, S. P. (2011). Attitudes of Indians Towards Service Quality for Life Insurance in India. International Journal of Research in Computer Application \& Management, 1(9), 57-63.

Prakash, G. (2011). Service quality in supply chain: empirical evidence from Indian automotive industry. Supply Chain Management: An International Journal, 16(5), 362-378.

Prakash, G. (2014). QoS in the internal supply chain: the next lever of competitive advantage and organisational performance. Production Planning \& Control, 25(7), 572-591.

Robson, C. (2002). Real world research. 3. uppl.

Rodrigues, L. L., Barkur, G., Varambally, K. V. M., \& Golrooy Motlagh, F. (2011). Comparison of SERVQUAL and SERVPERF metrics: an empirical study. The TQM Journal, 23(6), 629-643.

Sachdev, S. B., \& Verma, H. V. (2004). Relative importance of service quality dimensions: a multisectoral study. Journal of Services Research, 4(1), 93.

Saleh, F., \& Ryan, C. (1991). Analysing service quality in the hospitality industry using the SERVQUAL model. Service Industries Journal, 11(3), 324-345.

Santos, J. (2003). E-service quality: a model of virtual service quality dimensions. Managing Service Quality: An International Journal, 13(3), 233-246.

Saraph, J. V., Benson, P. G., \& Schroeder, R. G. (1989). An instrument for measuring the critical factors of quality management. Decision sciences, 20(4), 810-829.

Schvaneveldt, S. J., Enkawa, T., \& Miyakawa, M. (1991). Consumer evaluation perspectives of service quality: evaluation factors and two-way model of quality. Total Quality Management, 2(2), 149162. 
Seth, A., Momaya, K., \& Gupta, H. M. (2008). Managing the customer perceived service quality for cellular mobile telephony: An empirical investigation. Vikalpa, 33(1), 19-34.

Seth, N., Deshmukh, S. G., \& Vrat, P. (2006). A framework for measurement of quality of service in supply chains. Supply Chain Management: An International Journal, 11(1), 82-94.

Singh, P. J., Feng, M., \& Smith, A. (2006). ISO 9000 series of standards: comparison of manufacturing and service organisations. International Journal of Quality \& Reliability Management, 23(2), 122142.

Smith, L., Maull, R., \& CL Ng, I. (2014). Servitization and operations management: a service dominant-logic approach. International Journal of Operations \& Production Management, 34(2), 242269.

Soteriou, A. C., \& Stavrinides, Y. (2000). An internal customer service quality data envelopment analysis model for bank branches. The International Journal of Bank Marketing, 18(5), 246-252.

Stank, T. P., Keller, S. B., \& Daugherty, P. J. (2001). Supply chain collaboration and logistical service performance. Journal of Business Logistics, 22(1), 29-48.

Stanley, L. L., \& Wisner, J. D. (2002). The determinants of service quality: issues for purchasing. European Journal of Purchasing \& Supply Management, 8(2), 97-109.

Sureshchandar, G. S., Rajendran, C., \& Anantharaman, R. N. (2002). Determinants of customer-perceived service quality: a confirmatory factor analysis approach. Journal of services Marketing, 16(1), 9-34.

Sotoudeh-Anvari, A., Sadjadi, S., Molana, S \& Sadi-Nezhad, S. (2018). A new MCDM-based approach using BWM and SAW for optimal search model.Decision Science Letters, 7(4), 395-404.

Tanaka, J. S. (1987). "How big is big enough?": Sample size and goodness of fit in structural equation models with latent variables. Child development, 134-146.

Trochim, W. M. (2007). Research methods, Biztantra, New Delhi.

Tsang, N. K., Lee, L. Y. S., \& Qu, H. (2015). Service quality research on China's hospitality and tourism industry. International Journal of Contemporary Hospitality Management, 27(3), 473-497.

Wattanakamolchai, S. (2008). The evaluation of service quality by socially responsible customers (Doctoral dissertation, Virginia Tech).

Zhu, F. X., Wymer, W., \& Chen, I. (2002). IT-based services and service quality in consumer banking. International Journal of Service Industry Management, 13(1), 69-90.

Zhu, X., \& Zolkiewski, J. (2016). Exploring service adaptation in a business-to-business context. Journal of Service Theory and Practice, 26(3), 315-337. 


\section{Annexure-1}

\section{INTERVIEW SCHEDULE}

\section{SECTION-A: ASSESSMENT OF EMPLOYEE SERVICE QUALITY}

\section{Directions:}

- Please rate the degree/level/extent of performance of your employees/colleagues (general perception about your employees) by responding to the following questions.

- Please encircle one of the numbers from [1] to [5] or [U] to express your opinion. Scale: [1] Very Low [2] Low [3] Medium [4] High [5] Very High [U] Unable to respond

Organization's Assessment of Performance of Employees i.e. Employee Service Quality (ESQ)

\begin{tabular}{|l|l|}
\hline Issues (What are employees doing for your organization?) & Performance Rating of Employees \\
\hline
\end{tabular}

\begin{tabular}{|l|l|l|}
\hline Reliability & \multicolumn{2}{|l|}{ Per } \\
\hline Your employees consistently deliver quality products /services & 1 & 2 \\
\hline Your employees deliver correct quantity at right time & 1 & 2 \\
\hline Your employees are technically sound \& competent & 1 & 2 \\
\hline Your employees are prompt in action & 1 & 2 \\
\hline Your employees are trustworthy \& honest in operations & 1 & 2 \\
\hline Your employees maintain confidentiality in operations & 1 & 2 \\
\hline Assurance &
\end{tabular}

\section{Assurance}

Your employees have knowledge/skills/expertise to perform as per your organization's requirements

Your employees are consistently courteous and have a positive attitude towards organization

Your employees share relevant information among colleagues

Your employees are fast in informing about progress/feedback

Your employees are innovative in operation

Your employees are flexible to adapt as per requirements

Your employees have strong market reputation

Your employees use latest Information and Communication Technol-

ogies (ICT) tools

\begin{tabular}{|l|l|l}
\hline 2 & 3 & 4 \\
\hline 2 & 3 & 4 \\
\hline 2 & 3 & 4 \\
\hline 2 & 3 & 4 \\
\hline 2 & 3 & 4 \\
\hline 2 & 3 & 4 \\
\hline
\end{tabular}

\begin{tabular}{|l|l|}
\hline 4 & 5 \\
\hline 4 & 5 \\
\hline 4 & 5 \\
\hline 4 & 5 \\
\hline 4 & 5 \\
\hline 4 & 5 \\
\hline
\end{tabular}

\begin{tabular}{|l|l|}
\hline 5 & $\mathrm{U}$ \\
\hline 5 & $\mathrm{U}$ \\
\hline 5 & $\mathrm{U}$ \\
\hline 5 & $\mathrm{U}$ \\
\hline 5 & $\mathrm{U}$ \\
\hline 5 & $\mathrm{U}$ \\
\hline
\end{tabular}

Tangibles

Your employees use right tools and equipment

Your employees make proper use of physical facilities

\begin{tabular}{|l|l|l|l|l|l|}
\hline & 2 & 3 & 4 & 5 & $\mathrm{U}$ \\
\hline 1 & 2 & 3 & 4 & 5 & $\mathrm{U}$ \\
\hline 1 & 2 & 3 & 4 & 5 & $\mathrm{U}$ \\
\hline 1 & 2 & 3 & 4 & 5 & $\mathrm{U}$ \\
\hline 1 & 2 & 3 & 4 & 5 & $\mathrm{U}$ \\
\hline 1 & 2 & 3 & 4 & 5 & $\mathrm{U}$ \\
\hline 1 & 2 & 3 & 4 & 5 & $\mathrm{U}$ \\
\hline 1 & 2 & 3 & 4 & 5 & $\mathrm{U}$ \\
\hline
\end{tabular}

Empathy

Your employees understand the requirements of the organization

Your employees care for the convenience of co-workers

\section{Responsiveness}

Your employees have willingness to work for the organization and maintain a positive work environment

Your employees are prompt in handling complaints

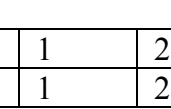

\begin{tabular}{l|l}
2 & 3 \\
\hline 2 & 3
\end{tabular}

\begin{tabular}{l|l}
3 & 4 \\
\hline 3 & 4 \\
\hline
\end{tabular}

\begin{tabular}{l|l|l|}
\hline 4 & 5 & $\mathrm{U}$ \\
\hline 4 & 5 & $\mathrm{U}$ \\
\hline
\end{tabular}

\section{Fairness}

Your employees demand just salary and allowances in comparison with employees in your competitor organizations

Your employees demand just service terms \& conditions in comparison with those in your competitor organizations

\begin{tabular}{l|l|l|l|l|l}
1 & 2 & 3 & 4 & 5 & $\mathrm{U}$ \\
1 & 2 & 3 & 4 & 5 & $\mathrm{U}$ \\
\hline
\end{tabular}

\begin{tabular}{l|l|l}
\hline 1 & 2 & 3 \\
\hline 1 & 2 & 3 \\
\hline
\end{tabular}

\begin{tabular}{|l|l|}
\hline 3 & 4 \\
\hline 3 & 4 \\
\hline
\end{tabular}

\begin{tabular}{|l|l|l|}
\hline 4 & 5 & $\mathrm{U}$ \\
\hline 4 & 5 & $\mathrm{U}$ \\
\hline
\end{tabular}

\begin{tabular}{|l|l|l|l|l|l|}
\hline 1 & 2 & 3 & 4 & 5 & $\mathrm{U}$ \\
\hline 1 & 2 & 3 & 4 & 5 & $\mathrm{U}$ \\
\hline
\end{tabular}

OVERALL SERVICE QUALITY

\begin{tabular}{l|l|l}
1 & 2 & 3
\end{tabular}




\section{SECTION-B: DEMOGRAPHIC INFORMATION}

A. About Organization

Name of Organization :

Nature of Organization :

Small or medium scale :

Turnover of Organization :

Number of Employees :

Year of Establishment :

B. About Respondent

Name (Optional) :

Designation :

Years in current position :

Qualification :

Email ID \& Contact No. : : 